\title{
Update on the roles of distal airways in asthma
}

\author{
P-R. Burgel, J. de Blic, P. Chanez, C. Delacourt, P. Devillier, A. Didier, J-C. Dubus, \\ I. Frachon, G. Garcia, M. Humbert, F. Laurent, R. Louis, A. Magnan, B. Mahut, \\ T. Perez, N. Roche, I. Tillie-Leblond, M. Tunon de Lara and D. Dusser
}

ABSTRACT: The present review is the summary of an expert workshop that took place in Vence (France) in $\mathbf{2 0 0 7}$ on the role of distal airways in asthma. The evidence showing inflammation and remodelling in distal airways, and their possible involvement in asthma control and natural history, was reviewed. The usefulness and limitations of various techniques used for assessing distal airways were also evaluated, including pulmonary function tests and imaging. Finally, the available data studying the benefit of treatment better targeting distal airways in asthma was examined. It was concluded that both proximal and distal airways were involved in asthma and that distal airways were the major determinant of airflow obstruction. Inflammation in distal airways appeared more intense in severe and uncontrolled asthma. Distal airways were poorly attained by conventional aerosol of asthma medications owing to their granulometry, being composed of 3-5 $\mu \mathrm{m}$ particles. Both proximal and distal airways might be targeted either by delivering medications systemically or by aerosol of extra-fine particles. Extra-fine aerosols of long-acting $\beta$-agonists, inhaled corticosteroids or inhaled corticosteroid/long-acting $\beta$-agonist combinations have been shown in short-term studies to be not inferior to non-extra-fine aerosols of comparators. However, available studies have not yet demonstrated that extra-fine inhaled medications offer increased benefit compared with usual aerosols in asthmatic patients.

KEYWORDS: Airway inflammation, airway remodelling, alveoli, asthma, bronchioles, distal airway

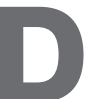
istal airways are classically defined as those of $<2 \mathrm{~mm}$ internal diameter. Although these airways contribute little to airflow obstruction in normal airways, studies have revealed that distal airways accounted for up to $50-90 \%$ of total airflow resistance in asthmatics [1], implying that distal airways were the main site of airflow obstruction in asthmatics. Studies of distal airways have proved difficult, owing to their small size and their peripheral location. Thus, it is not surprising that the roles of distal airways in the natural history of asthma have long been neglected.

Asthma therapies have dramatically improved over the past decades. Inhaled therapeutics, including corticosteroids and $\beta_{2}$-agonists, are the mainstream drugs used in asthmatic subjects. Although these drugs are very efficient in most cases, three unmet needs are identified using current therapies. First, achieving asthma control is recommended by guidelines [2] but appears difficult to obtain in most patients. The Gaining
Optimal Asthma Control study of 3,400 asthmatic patients over a 12-month period evaluated the percentage of subjects achieving control using inhaled fluticasone or inhaled fluticasone/salmeterol in three groups of patients: corticosteroidfree subjects, and those receiving low and moderate doses of inhaled corticosteroid (ICS) at baseline [3]. In this clinical study that used rigorous algorithms to adapt therapy, total control of asthma was obtained with fluticasone in only $40 \%, 28 \%$ and $16 \%$ in corticoid-free subjects and in low- and moderate-dose ICS users, respectively. The use of the fixed combination fluticasone/salmeterol increased the percentage of total control of asthma in only $50 \%, 44 \%$ and $29 \%$ of patients in these three groups, respectively [3]. Secondly, long-term longitudinal studies have revealed that asthmatic subjects have greater decline in lung function compared with normal subjects; importantly, it appears that current therapies do not interfere with the natural history of lung function decline in asthmatic subjects [4].

\section{AFFILIATIONS}

For affiliations, please see the Acknowledgements section.

CORRESPONDENCE

D. Dusser

Service de Pneumologie

Hôpital Cochin

27 rue du Faubourg

St Jacques 75679

Paris Cedex 14

France

E-mail: daniel.dusser@cch.aphp.fr

Received:

March 042009

Accepted:

March 062009

\section{PROVENANCE}

Publication of this peer-reviewed article was made possible by funding from Chiesi, France (secondary sponsor, European Respiratory Review issue 112). 
These studies suggest that current therapies have little effect on the development of airway structural abnormalities (a process known as remodelling), which potentially lead to bronchial obstruction. Thirdly, severe asthma represents nearly $10 \%$ of all asthma cases, but up to $30 \%$ of the cost, which is mostly related to resource utilisation (e.g. unscheduled medical visits and hospitalisations) due to insufficient asthma control [5, 6]. Taken together, these rather disappointing observations underscore the need for therapeutic improvement in asthma treatment.

Several strategies may be developed to improve asthma control and natural history. Guidelines have been released [2, 7] and better implementation and larger diffusion may contribute to improve the daily management of asthma by physicians and patients. Additionally, there is a need for novel molecules targeting structural abnormalities (remodelling), which are observed in subjects with chronic asthma (i.e. hypertrophy and hyperplasia of airway smooth muscle, basal membrane thickening and peribronchial fibrosis, and mucous hypersecretion). Furthermore, a potentially important improvement in asthma therapy may be obtained using molecules that target both proximal and distal airways. To date, granulometric properties of inhaled therapies (particles of 3-5 $\mu$ m mass median aerodynamic diameter) result in their preferential deposition in proximal airways. It is reasonable to speculate that drugs that could better target distal airways could contribute to the improvement of control and natural history of asthma. The present review is the summary of an expert workshop that took place in Vence (France) on November 22-23, 2007 and examined several questions related to distal airway involvement in asthma. The evidence linking inflammation and remodelling in distal airways, and their possible implication asthma control and natural history, was reviewed. Techniques that have been proposed to monitor distal airways in asthmatic subjects, including various measurements of distal airway function using pulmonary function tests and imaging, were also evaluated. Finally, the available literature compatible with the working hypothesis that targeting distal airways was beneficial to asthmatic subjects was examined.

\section{EVIDENCE FOR DISTAL AIRWAY IMPAIRMENT IN ASTHMA \\ Pathology of asthma: inflammation and remodelling in distal versus proximal airways}

Human airways divide into 24 airway generations, including trachea. Distal airways are located after the eighth generation down to terminal bronchioles and respiratory bronchioles, which contain occasional alveoli budding from their wall. Distal airways correspond to noncartilaginous airways and are usually defined by an internal diameter $<2 \mathrm{~mm}$ in adults. Obviously, this definition cannot be applied in children. Crosssectional area of the airways increases extremely rapidly in the respiratory zone (from 16th to 23rd generation). Although distal airways contribute little to airflow limitation in normal subjects, these airways are the main site of airflow obstruction in asthmatics.

Most bronchial structures are present throughout the bronchial tree [8]. Smooth muscle develops in utero from the 53rd day [9] and is mature at birth [10]. Muscle fibres are present at the alveolar duct opening. Smooth muscle contraction has different effects in distal versus proximal airways. In small and medium-sized airways, smooth muscle contraction results not only in reduced airway diameter but also in reduced airway length, leading to increased airway rigidity. Furthermore, age and sex influence the distribution of airway smooth muscle. In distal airways, smooth muscle accounts for $20 \%$ of airway wall thickness in adults versus $10 \%$ in children. Sex differences in airway smooth muscle distribution may also account for increased prevalence of asthma in young males and later onset of asthma in females [11, 12]. Early aggressions (e.g. neonatal mechanical ventilation and infectious bronchiolitis) may lead to increased smooth muscle mass. It is now established that smooth muscle hypertrophy is a specific feature of asthma potentially related to calcium-dependent enhanced mitochondrial biogenesis [13]. Increased angiogenesis (growth of new blood vessels from existing vessels) and vascular remodelling (structural abnormalities leading to enlargement of existing vessels) are found in asthmatic airways. These structural changes combined with increased vascular permeability induce plasma exudation and recruitment of circulating leukocytes. Altogether, these changes may result in airflow limitation that is more important in children than in adults [14]

Inflammation and remodelling are constant features of asthma; current evidence suggests that these features occur in asthmatic airways from nasal mucosa to alveolar structures [15]. Sampling of distal airways to evaluate inflammation and remodelling has proven more difficult than sampling of proximal airways. Distal airways may be sampled by studying lung tissue obtained in subjects dying of acute asthma, or in living asthmatics in tissue obtained surgically during lung resection or by transbronchial biopsies. Bronchoalveolar lavage fluid (BALF) analysis may also provide information regarding cellular infiltrates and inflammatory mediators present in distal airways [16].

\section{Fatal asthma}

Autopsy findings from asthma deaths provide useful information regarding inflammation and remodelling in proximal versus distal airways [17, 18]. Limitations of these studies include the usual lack of detailed clinical information, especially concerning the smoking status in these subjects. Furthermore, changes found in acute fatal asthma may not reflect findings in chronic asthma [17, 18]. FAUL et al. [19] found large numbers of eosinophils and lymphocytes in both proximal and distal airways in five patients deceased of acute asthma. In a study, in which subjects with acute fatal asthma were compared with subjects with mild to moderate asthma who died of unrelated causes, it was reported that subjects dying of acute severe asthma had increased numbers of eosinophils in proximal airways, whereas no difference was observed in distal airways [20]. Degranulated mastocytes were also increased in fatal asthmatic airways. In proximal airways, mastocytes were found in smooth muscle and submucosal glands, whereas these cells were found in smooth muscle and adventitia in distal airways [21, 22]. It was further shown that distribution of CD45+ leukocytes and eosinophils was localised in smooth muscle and alveolar attachments in distal airways, whereas these cells were found in the subepithelium in proximal airways [23]. KUYPER et al. [24] evaluated airway 
structural abnormalities in a large series of patients with acute fatal asthma $(n=93)$ compared with airways from control patients who died suddenly without pulmonary diseases. It was found that airway luminal obstruction by an exudate composed of mucus and cells was present in both proximal and distal conducting airways in most patients, and it was suggested that plugging by mucoinflammatory exudates was a major contributing cause of fatal asthma [24]. KUWANO et al. [25] also found important structural abnormalities in distal airways of subjects dying of acute fatal asthma: the adventitial, submucosal and muscle area of the asthmatic airways were greater than those of chronic obstructive pulmonary disease (COPD) subjects and control subjects.

\section{Lung obtained at surgery}

HAMID et al. [26] examined the inflammatory process in the central and peripheral airways of surgically resected lungs from asthmatic and nonasthmatic subjects. Airways from patients with asthma demonstrated significant increases in the numbers of T-cells and eosinophils compared with airways from nonasthmatic subjects. In asthma, numbers of activated eosinophils, but not T-cells, were significantly greater in small conducting airways compared with larger airways, leading the authors to conclude that that there was a similar but more severe inflammatory process present in the peripheral airways of patients with asthma [26]. Using in situ hybridisation, MinsHALl et al. [27] found that interleukin (IL)-4 and IL-5 mRNA-positive cells were increased in proximal and distal airways in asthmatics compared with normal subjects; in the asthmatic subjects, the expression of IL-5 mRNA was increased in the small airways compared with the large airways. Cells expressing mRNA for the chemokine monocytic chemotactic protein (MCP)-4 and eotaxin were also increased in airways of asthmatic patients compared with controls; similar levels of expression were found when comparing small and large asthmatic airways [28].

\section{Transbronchial biopsies}

BALzAR et al. [29] studied bronchial and transbronchial biopsies obtained in 20 severe asthmatic subjects and reported increased chymase-positive mast cells in distal airways, which were positively correlated with lung function. The roles of mastocytes in distal airways are currently unknown and deserve further investigation. BALZAR et al. [30] also showed that inflammatory cells were increased in distal airways compared with proximal airways from severe asthmatics. Studying subjects with severe asthma compared with moderate asthmatics and normal subjects, WeNZEL et al. [31] found increased neutrophils in both proximal and distal airways sampled by bronchial and transbronchial biopsies, respectively. In subjects with nocturnal (severe) asthma, KRAFT et al. [32] found increased numbers of eosinophils and T-lymphocytes in distal airways in comparison to proximal airways; CD4+ T-cells in alveolar tissue inversely correlated with forced expiratory volume in $1 \mathrm{~s}$ (FEV1). Taken together, these data suggest important roles for distal airway inflammation in severe asthma.

\section{BALF}

Nocturnal asthma is usually associated with poor control of asthma. Studies have evaluated cells and mediators present in
BALF in subjects with nocturnal asthma. Recruitment of inflammatory cells (polymorphonuclear leukocytes and eosinophils) was increased in subjects with nocturnal asthma [33]. Macrophage activation, reflected by the presence of reactive oxygen species, was also more intense in subjects with nocturnal asthma [34]. Furthermore, eosinophil chemokines (RANTES (regulated on activation, normal T-cell expressed and secreted), eotaxin-1 and -2, and MCP-3 and -4) were also increased in BALF of allergic asthmatic children [35]. Increased eosinophil numbers in BALF of asthmatic subjects were not related to disease severity, whereas neutrophilic inflammation was often correlated with disease severity [36-38]. Increase in interferon- $\gamma$ producing cells [39] and in interferon- $\gamma$ concentrations [40] were found in BALF of asthmatic children. Furthermore, young asthmatic children had increased activated macrophages that released pro-inflammatory mediators (e.g. thromboxan B2, leukotriene-B4 and tumour necrosis factor- $\alpha$ ) [41, 42]. Protease anti-protease balance may also be altered in asthmatic airways: BALF concentrations of matrix metalloprotease (MMP)9 and tissue inhibitor of metalloprotease (TIMP) 1 were found increased [43] or decreased [44] in asthmatic children and positive correlation was reported between MMP9/TIMP1 and nitric oxide output [44].

\section{Is it possible to monitor distal airway disease using bronchial biopsies and induced sputum?}

Few studies have compared inflammatory cells in proximal versus distal airways. Studies performed by CAROLL et al. [45] on lungs from subjects with fatal asthma and by HAMID et al. [26] in lung tissues obtained at surgery suggest that the cellular infiltrate observed in endobronchial biopsies reflects findings in distal airways.

Several investigators have compared cellular contents in BALF and in induced sputum. In healthy individuals, neutrophils are found in induced sputum, in which they represent $30-40 \%$ of total cells $[46,47]$, whereas these cells represent $<3 \%$ of total cells in BALF [48]. In asthmatics, eosinophils are usually more prominent in induced sputum compared with BALF [49-52]. It is concluded that induced sputum cannot be used to assess inflammation in distal airways.

\section{Conclusion on distal airway inflammation and remodelling}

The profile of cellular infiltrate and changes in structural cells are similar in distal versus proximal airways in most cases of asthma. However, several studies indicate a more intense and inflammatory infiltrate and cell activation in severe asthma, nocturnal asthma (an expression of uncontrolled asthma) and its ultimate state, i.e. fatal asthma.

In fatal asthma, studies have showed major alterations in distal airways, including epithelium, smooth muscle and mucus hypersecretion leading to distal airway plugging. Thus, pathological evidence indicates that distal airway inflammation and remodelling contribute substantially to the pathophysiology of severe asthma.

\section{Epidemiological evidence of distal airway impairment in asthma}

Impairment of distal airways in the natural history of asthma has been demonstrated in longitudinal studies of large paediatric cohorts. Results of these studies indicated that 
asthma is associated with significant impairment in the distal airways, which may be associated with asthma symptoms and may persist even when symptoms disappear. MOSTGAARD et al. [53] studied 1,319 schoolchildren (aged 8-10 yrs) and showed that forced expiratory flow at 75\% (FEF75\%) and 50\% (FEF50\%) of forced vital capacity (FVC) were significantly decreased in children with asthma symptoms versus asymptomatic children, whereas FEV1 was not significantly different. NAKADATE and KAWAGA [54] studied 325 children (aged 8-10 yrs) with longitudinal follow-up for 4 yrs: FEF50\% and forced expiratory flow at $25 \%$ of FVC were significantly decreased in children with a history of doctor diagnosed asthma, including those who remained asymptomatic over the study period.

Several factors have been associated with distal airway impairment in asthmatic children. This impairment is more important when asthma has started early, before age $5 \mathrm{yrs}$, or when asthma is persistent. BERHANE et al. [55] examined schoolchildren in a cohort of 2,277 fourth and seventh graders at least twice during a 4-yr follow-up period. In both males and females with longer time ( $>6 \mathrm{yr}$ ) since asthma diagnosis, larger deficits in forced expiratory flow between $25 \%$ and $75 \%$ of FVC (FEF25\%-75\%; -7\% and $-9 \%$, respectively) and in FEF75\% $(-8 \%$ and $-14 \%$, respectively) were seen [55]. Similarly, in children for whom asthma was reported to have been diagnosed before age 3 yrs, FEF25-75\% (-19\% and $-15 \%$, respectively) and in FEF75\% (-23\% for both males and females) were markedly decreased [55]. In all cases, distal airway impairment was more pronounced than proximal airway impairment. Furthermore, increase in distal airway impairment persisted and increased with age, predominantly in male children. Other factors associated with distal airway impairment in asthmatic children include the presence of atopy [56], in utero exposure to maternal smoking [57], poor airway function shortly after birth $[58,59]$ and respiratory infections during infancy $[60,61]$.

Several studies indicate that airway impairment, including that of distal airways, occurs early in life. Between 1980 and 1984, 1,246 children were recruited in a population-based birth cohort in Tucson, AZ, USA. Longitudinal follow-up of children through adolescence revealed that at age 16 yrs both transient early and persistent wheezers had significantly lower FEF25-75\% compared with never wheezers [4]. Late-onset wheezers (after age $3 \mathrm{yrs}$ ) had levels of lung function similar to those of never wheezers at age 16 yrs. The authors concluded that patterns of wheezing prevalence and levels of lung function are established by age 6 yrs and do not appear to change significantly by age 16 yrs in children who start having asthma-like symptoms during preschool years. Distal airway obstruction related to early wheezing episodes may be easily demonstrated by age 5 yrs $[62,63]$. In a prospective study of infants who had had at least three episodes of wheezing, bronchial hyperreactivity at age 16 months was predictive of impaired lung function in children at age 9 yrs, strongly indicating early airway remodelling in infantile asthma [64]. It has been previously shown in studies of asthmatic subjects from age 9 to 26 yrs that lung function in adult asthma may be determined primarily in early childhood [65, 66]. It is proposed that lung function in asthmatic subjects may be determined in early years of life.

\section{ASSESSEMENT OF DISTAL AIRWAYS IN ASTHMA: PULMONARY FUNCTION TESTS \\ Invasive measurements}

Bronchioles $<2 \mathrm{~mm}$ internal diameter were originally described as the "quiet zone" of the lungs and contributing to $<10 \%$ of the total resistance to airflow in normal airways [67]. Using a model of airway narrowing, investigators subsequently reported that increase in distal airway wall thickness, which occurs in asthmatic airways, contributes to increased airflow resistance after smooth muscle contraction [68]. Direct bronchoscopic measurement of intrabronchial pressure in stable asthmatics with airflow obstruction revealed that distal airways contributed up to $60 \%$ total airway resistance [1]. Peripheral airway responsiveness induced by histamine challenge was significantly enhanced in asthmatic subjects relative to normal controls [69], further implicating distal airways in airflow limitation in asthma. Premature airway closure due to loss of lung elastic recoil caused by disruption of alveolar attachments has also been suggested to contribute to increased peripheral resistance and air trapping in severe asthmatics [70]. Altogether, direct (invasive) measurements of airway resistance indicate that distal airways play important roles in increased airway resistance in acute and chronic asthma.

\section{Noninvasive measurements}

Spirometry and plethysmography

Pulmonary function tests remain the most widely available noninvasive methods to assess airflow limitation in distal airways. During maximal expiration, proximal airways contribute mostly to measurements assessed during the early phase of expiration, including FEV1, whereas distal airways are believed to contribute most to the end of expiration [71]. Therefore, FEF25-75\% and FEF50\% have been suggested to reflect distal airway obstruction and have been used in epidemiological and therapeutic studies involving asthmatic subjects [72-75]. However, FEF25-75\% and FEF50\% are highly variable spirometric tests [76]. First, normal values vary greatly [77] and can be interpreted only when associated with normal FVC. Secondly, the lower limit of normal value of FEF25-75\%, defined as under the fifth percentile of the predicted value, corresponds to a difference from the predicted value $\geqslant 1.71 \mathrm{~L} \cdot \mathrm{s}^{-1}$ in males and $1.40 \mathrm{~L} \cdot \mathrm{s}^{-1}$ in females. Thirdly, FEF25-75\% and FEF50\% cannot be used to monitor reversibility to bronchodilator when FVC has increased significantly. Finally, no cut-off value of reversibility has been established for these variables. It is concluded that, although FEF25-75\% and FEF50\% are easily available, these measurements should be interpreted with caution and are of limited reliability to assess distal airway function.

Lung hyperinflation is defined by increased functional residual capacity [78], which always involves increased residual volume (RV). Investigators reported that RV is increased in severe versus moderate asthmatics [79]. In asthma, contrary to COPD, total lung capacity (TLC) is usually within normal values [79], resulting in increased RV/TLC in severe asthmatics. Mechanisms leading to lung hyperinflation in asthmatics include expiratory airflow limitation and premature closure of small airways [80], activity of inspiratory muscles at the end of expiration and reduced pulmonary 
elasticity [81]. Although not definitively proven, it is generally accepted that lung hyperinflation is related to abnormalities in distal airways [77]. Thus, positive correlations were found between alveolar eosinophils and lung hyperinflation (increased TLC and RV) in an immunohistochemical study of transbronchial biopsies obtained in asthmatic subjects [82]. Assessment of lung hyperinflation is a relatively simple method for assessing distal airways in severe asthmatics. A recent study in a large population of nonsevere $(n=382)$ and severe $(n=287)$ asthma subjects assessed the presence of air trapping by reduction of FVC \% predicted or increased RV/ TLC. For a given level of airway obstruction (FEV1/FVC), air trapping was much higher in patients with severe asthma [83]. Impact of therapy on lung hyperinflation is an interesting area for study in severe asthma.

The ratio of FVC to slow vital capacity (SVC) has been suggested to be an indirect marker of distal airway abnormalities, reflecting either small airway obstruction or loss of elastic recoil in the parenchyma [84]. This rather simple marker of distal airway involvement has been studied in limited numbers of severe asthmatics [84]: in a single study, FVC/SVC was decreased in subjects with eosinophilic versus noneosinophilic severe asthma (FVC/SVC 88\% versus 97\%, respectively) [84]. Further evaluation of this potentially useful measurement is warranted in subjects with severe asthma.

\section{Pulmonary resistance measurements}

The gold standard for measurement of total pulmonary resistance involves the use of an oesophageal balloon to measure pleural pressure. Several noninvasive alternatives to this invasive technique have been developed. First, airway resistance (Raw), airway conductance (Gaw; 1/Raw) and specific airway conductance (sGaw; Gaw/TLC) may be obtained during body plethysmography [85]. Although Raw is elevated and sGaw is decreased in subjects with obstructive lung disease, these variables do not specifically reflect distal airway abnormalities. Secondly, interruption of tidal breathing has been proposed to provide noninvasive measurement of airway resistance, especially in children [86]. This technique has been seldom used in adults and does not provide data specifically related to distal airways. Thirdly, investigators proposed the use of forced oscillation technique to measure respiratory system resistance (Rrs) [87]. This method is particularly attractive in children as it requires only passive cooperation from the subject, who breathes quietly at tidal volume during the test. A predominant increase of Rrs at low frequencies $(<10-15 \mathrm{~Hz})$ called frequency dependence has been shown to reflect obstruction in distal airways in various obstructive lung diseases, including asthma [87-91]. Low frequency Rrs were increased in asthmatic children with mild airway obstruction (FEV1 $>80 \%$ pred and FEF25-75\% $<80 \%$ pred) [92]. In adults, subjects with moderate and severe asthma also exhibited a marked frequency dependence of $\operatorname{Rrs}$ [88].

\section{Nitrogen washout}

Assessment of computerised single-breath nitrogen washout is another potentially useful measurement of distal airway dysfunction in asthma. Normally, small airway closure occurs at low pulmonary volume (close to RV) during expiration; early expiratory small airway closure at higher pulmonary volume results in air trapping. Small airway closure may be assessed by measurements of expiratory nitrogen concentrations from RV to TLC in patients breathing pure oxygen. The slope of the nitrogen alveolar plateau is calculated by computer analysis of best fit line through phase III of the expiratory volume-concentration curve. Closing volume (phase IV) and closing capacity (RV plus closing volume) can be determined. Using computerised analysis of single-breath nitrogen washout, BOURDIN et al. [93] showed that poor asthma control was correlated with increase in closing volume and phase III slope. Comparing severe asthmatics with wellcontrolled disease to severe asthmatics with frequent exacerbations, investigators also reported that increased closing volume correlated with frequent asthma exacerbations and $\mathrm{RV} / \mathrm{TLC}$ ratio [94]. In the latter study, pulmonary volumes measured by plethysmography were not different between groups, suggesting that inflammatory mechanisms in distal airways contributed to poor asthma control [94].

VERBANCK et al. [95] described a novel method of nitrogen multiple-breath washout to derive the two variables Scond (index of conductive ventilation heterogeneity) and Sacin (index of acinar ventilation heterogeneity) as measurements of ventilation inhomogeneity in conductive and acinar zones of the lungs, respectively. The authors evaluated the effects of salbutamol on ventilatory heterogeneity in asthmatic subjects and reported that the most consistent pattern of non- $\beta_{2}-$ agonist-reversible ventilatory heterogeneity is in the conductive lung zone, most probably in the small conductive airways [96]. It was suggested that drugs aimed at the relief of the non$\beta_{2}$-agonist-reversible component in mild asthma should be preferentially targeted to the small conductive airways. VERBANCK et al. [97] further showed that among stable patients with asthma, those with acinar lung zone abnormality at baseline are more likely to elicit a functional benefit from an extra-fine steroid aerosol. Although nitrogen multiple-breath washout appears an appealing technique for measurement of distal airway abnormalities, the lack of standardisation and the absence of commercially available devices currently preclude its large clinical use.

\section{Exhaled nitric oxide}

Measurement of the exhaled fraction of nitric oxide ( $F \mathrm{eNO})$ has been proposed to be a noninvasive tool for the evaluation of airway inflammation in asthmatic airways. Several studies have suggested that variations in FeNO, which correlated with airway eosinophils and asthma symptoms, may be useful in monitoring asthma control [98-100]. Recently published evidence has suggested that $\mathrm{NO}$ is produced both in proximal and in distal airways. First, measurement of NO accumulation in the bronchiolar gases during bronchoscopy suggested that local synthesis of NO occurred within distal airways [101]. Epithelial inducible NO synthase activity is the major determinant of NO concentration in exhaled breath [102]. NO synthase 2 is expressed in airway epithelium in proximal airways and is probably expressed in small airway epithelium [102]. Secondly, increased exhaled NO is found in diseases characterised by distal airway involvement including alveolitis [103], fibrosing alveolitis [104], liver cirrhosis [105] and scleroderma lung disease [106]. 
The production of $\mathrm{NO}$ can be assessed by measuring FeNO during a prolonged expiration at constant expiratory flow. This technique gives no information regarding the origin of exhaled NO. Analysis of the relationship between exhaled NO and expiratory flow allows estimation of other parameters of $\mathrm{NO}$ exchange, including the alveolar NO concentration (CalvNO) [107-109]. The interpretation of multiple measurement and calculation of CalvNO may provide information about distal airway inflammation. Measurement of CalvNO correlated with BALF eosinophils in severe asthmatic subjects [110] and in allergen-challenged mice [111], supporting the hypothesis that alveolar $\mathrm{NO}$ is a measure of distal airway inflammation. Increased CalvNO was also found in symptomatic asthmatic subjects with normal lung function, suggesting a role of inflammation in distal airways $[112,113]$. Furthermore, CalvNO was found to correlate with distal airway obstruction, as measured by spirometry [113] or single-breath nitrogen test [114].

A summary of usefulness and limitations of pulmonary function tests for the assessment of distal airway involvement in asthma is provided in table 1.

\section{ASSESSMENT OF DISTAL AIRWAYS IN ASTHMA: IMAGING \\ High-resolution computed tomography}

Among the imaging techniques, high-resolution computed tomography (HRCT) has been best evaluated and has proven the most simple and cost-effective to perform. Technical improvement and the favourable air-filled lung have resulted in dramatically decreasing the irradiation burden: HRCT examinations using a low dose of $\sim 1$-yr natural irradiation are performed even during infancy.

Normally, bronchioles $<2 \mathrm{~mm}$ diameter cannot be seen using HRCT because bronchiolar walls are thin structures that are beneath the resolution of this technique. However, several morphological changes related to small airway disease can be detected in asthmatic airways including cylindrical bronchiolectasies and air trapping, a visual assessment of modified attenuation coefficient of the lung during expiration [115-117]. Pulmonary density, measured in areas distinct from main bronchi and large pulmonary vessels, is determined by intrapulmonary air, lung parenchyma, bronchiolar and capillary walls, and capillary blood. Modifications in any of these structures may result in variations of lung density, which may be diffuse or patchy. STERN and WEBB [118] have found that lung attenuation changed during a forced inspiratory and expiratory manoeuvre. Absence of increased density during expiration reflects air trapping related to distal airway obstruction.

Air trapping and lung attenuation may be evaluated using semiquantitative (visual) techniques, but accuracy and reproducibility of these techniques are poor. Investigators have developed semi-automated evaluation algorithms that involve isolation of lung parenchyma by fast contour tracking and definition of subregions by shrinking, radial segmenting, and anteroposterior subdividing of the left and the right lung. Using these algorithms, global and regional mean density values and histogram parameters can be extracted with increased accuracy and reproducibility [119, 120]. Quantitative assessment of air trapping necessitates the study of computed tomography images obtained during expiration.
This can be achieved by using HRCT with spirometric gating, allowing for measurement of lung attenuation at various lung volumes [121, 122], but the technique is not routinely used. Finally, computed tomography scan studies have been performed after methacholine-induced bronchoconstriction [123] and salbutamol-induced bronchodilation [124]. After methacholine challenge, patients with asthma had significant decrease in the median and lowest 10th percentile regions of the attenuation curves [123].

Mosaic patterns of attenuation and air trapping are not specific to asthma and were first described in bronchiolitis obliterans. Although severe asthma can be completely impossible to distinguish from bronchiolitis obliterans on the basis of computed tomography, mosaic pattern of attenuation, when present, is highly suggestive of bronchiolitis obliterans [125]. Air trapping may be observed in all diseases that affect distal airways. Air trapping has also been reported in normal subjects and its prevalence increases with age and tobacco smoking [126]

Investigators have studied correlations between HRCT findings, asthma severity, symptoms and pulmonary function evaluating distal airways. UEDA et al. [127] have shown that modifications of lung density at various pulmonary volumes correlated with abnormalities in distal airways and asthma severity. LEE et al. [128] showed that centrilobular opacities were more prevalent among subjects with near-fatal asthma, and that these abnormalities were partially reversible after the successful control of asthma symptoms. In children, JAIN et al. [129] reported that decreased lung density correlated with increased TLC and RV/TLC ratio, and also correlated with airway resistance measured by forced oscillations [129].

Several studies have used variations in lung density as a mean of assessing the efficacy of inhaled [122, 130,131] or systemic [132] therapy. A randomised study has evaluated HRCT findings in subjects treated with inhaled steroids, by comparing extra-fine particles of hydrofluoroalkane-beclomethasone dipropionate (HFA-BDP) that are deposited across all sizes of airways and conventional beclomethasone dipropionate that are deposited mostly in proximal airways [130]. HCRT measurements of lung density were performed at baseline and after 4 weeks of inhaled steroids. The study showed decreased air trapping in subjects treated with HFA-BDP extra-fine aerosol and less increase in air trapping after methacholine challenge [130]. These differences contrasted with the lack of clinical difference between groups with respect to improvement in symptoms, spirometry or methacholine responsiveness assessed by FEV1, except for a greater reduction in breathlessness in the HFA-BDP extra-fine aerosol group [130]. ZEIDLER et al. [132] measured air trapping using HRCT before and after methacholine challenge in asthmatic subjects randomised between placebo and oral montelukast. ZEIDLER et al. [132] reported that reduction in air trapping correlated with improved health-related quality of life but not with global measures of distal airways physiology, indicating that computed tomography may be more sensitive to changes in distal airways than conventional physiological studies.

\section{Other imaging techniques}

Magnetic resonance imaging (MRI) is not classically recommended for exploration of distal airways because its spatial 
TABLE 1 Usefulness and limitations of explorations of distal airways in asthma

\begin{tabular}{|c|c|c|}
\hline Methods & Parameters & Usefulness/limitations \\
\hline \multirow[t]{4}{*}{ Spirometry } & FEF25-75\% & Useful if FVC normal \\
\hline & FEF50\% & Useful if $F V C$ normal \\
\hline & & Large variations in normal values \\
\hline & FVC/SVC & Potentially useful \\
\hline \multirow{3}{*}{ Plethysmography } & & Indirect link to distal airways \\
\hline & & Further studies required \\
\hline & Raw and sGaw & Do not specifically reflect distal airway abnormalities \\
\hline Interruption of tidal breathing ${ }^{\#}$ & Airway resistance & Not specific for distal airways \\
\hline \multirow[t]{2}{*}{ Forced oscillations $^{\#}$} & Distal airway resistance & Good sensitivity/specificity \\
\hline & & Not widely available \\
\hline \multirow[t]{2}{*}{ Multiple breath } & Scond and Sacin & Good sensitivity/specificity \\
\hline & & Not commercially available \\
\hline \multicolumn{3}{|l|}{ Exhaled NO\# } \\
\hline Constant expiratory flow & FeNO & Do not specifically reflect distal airway abnormalities \\
\hline Multiple expiratory flow & CalvNo & Further studies required \\
\hline \multirow{2}{*}{$\mathrm{HRCT}^{\#}$} & Lung attenuation (semiquantitative) & Not reproducible \\
\hline & Lung attenuation (quantitative) & Requires expert radiologists and specific software/spirometric gating \\
\hline Other imaging techniques ${ }^{\#}$ & Not fully determined & High cost \\
\hline MRI (hyperpolarised gas) & & Low availability \\
\hline Technegas SPECT & & Few studies \\
\hline \multicolumn{3}{|l|}{ PET } \\
\hline Bronchoscopy & Direct measurement of airway resistance & Invasive \\
\hline
\end{tabular}

FEF25-75\%: mean forced expiratory flow between $25 \%$ and $75 \%$ of forced vital capacity (FVC); FEF50\%: forced expiratory flow at $50 \%$ of FVC; SVC: slow vital capacity; RV: residual volume; TLC: total lung capacity; Raw: airway resistance; SGaw: specific airway conductance; Scond: ventilation inhomogeneity in conductive zones of the lungs; Sacin: ventilation inhomogeneity in acinar zones of the lungs; FeNO: exhaled nitric oxide fraction; CalvNO: alveolar nitric oxide concentration; HRCT: high-resolution computed tomography; MRI: magnetic resonance imaging; SPECT: single photon emission computed tomography; PET: positron emission tomography; BALF: bronchoalveolar lavage fluid. ${ }^{\#}$ : these techniques have been used in research protocols or single-centre studies but their use for assessment of distal airways requires expertise that is not available in all centres.

resolution is relatively poor. Furthermore, only a weak signal is generated by intrapulmonary air, and air-tissue interface may generate magnetic fields. However, with the use of hyperpolarised gas (e.g. helium) static and dynamic imaging of pulmonary ventilation may be obtained. MRI studies in asymptomatic asthmatic subjects have revealed ventilation defects distributed throughout the lungs; these observations, which were not found in normal subjects, have been ascribed to involvement of distal airways [133]. Defects in ventilation were found to be increased after exercise testing or methacholine challenge in asthmatic subjects [134]. Although interesting, this technique is complex and cannot be used routinely.
Pellegrino et al. [135] studied regional expiratory flow limitation using Technegas single photon emission computed tomography. Although heterogeneity of Technegas accumulation in proximal airways after methacholine challenge was shown, this technique has not sufficient spatial resolution to identify changes in distal airways. Positron emission tomography using N13 has been used in research studies to evaluate ventilation/perfusion ratio in alveoli. Although these studies were useful in proposing theoretical models explaining ventilation heterogeneity in asthmatic airways, this technique cannot be proposed because of its cost and high irradiation [136, 137]. 


\section{TREATMENTS TARGETING DISTAL AIRWAYS IN ASTHMA: CLINICAL STUDIES}

Current therapy for asthma is largely based on inhaled drugs with particle size $3-5 \mu \mathrm{m}$. Properties of $3-5 \mu \mathrm{m}$ particles predict that drug deposition occurs predominantly in proximal airways and that only limited numbers of particles deposit in distal airways. Two strategies are possible for targeting distal airways in asthma. The first strategy consists of the delivery of medications p.o. or intravenously. The second strategy consists of inhaled medications using extra-fine particles, which deposit both in proximal and in distal airways.

Delivery of medications p.o. or intravenously is a way to target all areas of the lung, including distal airways. Oral corticosteroids are very efficient in maintaining asthma control, but their use is limited by unacceptable side-effects. Two studies have evaluated the effects of oral montelukast, a leukotriene antagonist, on distal airways in asthma [132, 138]. ZEIDLER et al. [132] studied air trapping at residual volume using HRCT before and after methacholine challenge. Montelukast decreased air trapping before, but not after methacholine challenge. This was paralleled by improvements in asthma symptoms and health-related quality of life. In another placebo-controlled study, distal airway function was assessed using conductance and residual volume [138]. Treatment with montelukast resulted in improvement in FEV1 and in specific conductance; improvement in asthma symptoms was also observed and was correlated with improvement in residual volume. In children, montelukast was also shown to improve measurements assessing distal airway obstruction [139, 140]

Only few studies have explored potential clinical benefits of inhaled drugs delivered as extra-fine particles via metered-dose inhaler (MDI) and even fewer have compared the same drug administered as aerosol particles of different sizes. In a randomised, double-blind, placebo-controlled study, 12 asthmatics inhaled technetium-99m-labelled monodispersed albuterol aerosols of 1.5-, 3- and 6- $\mu \mathrm{m}$ mass median aerodynamic diameters at slow $\left(30-60 \mathrm{~L} \cdot \mathrm{min}^{-1}\right)$ and fast $\left(>60 \mathrm{~L} \cdot \mathrm{min}^{-1}\right)$ inspiratory flows [141]. Lung and extrathoracic aerosol deposition were quantified using scintigraphy. Smaller particles achieved greater total lung deposition, farther distal airways penetration, and more peripheral lung deposition [141]. However, larger particles achieved greater bronchodilation than the marketed 200- $\mu$ g MDI albuterol using a spacer. Faster inspiration flows decreased lung deposition and caused less bronchodilation for the larger particles but did not alter increase in FEV1 with the smaller particles $(1.5 \mu \mathrm{m})$, resulting in a better bronchodilation with the $1.5-\mu \mathrm{m}$ particles compared with the 3 and $6-\mu \mathrm{m}$ particles [141]. Lung deposition increases with increasing particle size from 0.5 to $10 \mu \mathrm{m}$ under tidal breathing conditions [142]. However, single-breath inhalation associated with deeper breaths and increased lung residence time favour the deposition and lung penetration of the smaller particles [143]. Lung deposition in healthy nonsmoking volunteers of radiolabelled HFA-BDP with a mass median aerodynamic diameter of $0.9 \mu \mathrm{m}$ was greater compared with radiolabelled CFC-fluticasone propionate with a diameter of $2.0 \mu \mathrm{m}$ and radiolabelled CFC-BDP with a diameter of $3.5 \mu \mathrm{m}$ [144]. Three pharmacokinetic trials in asthmatic patients also demonstrated greater airways availability of HFA-BDP extra-fine aerosol and suggest that lower total daily doses of HFA-BDP is required than CFC-BDP [145]. The welldesigned study of BUSSE et al. [146] investigated the efficacy of HFA-BDP extra-fine aerosol and CFC-BDP at daily doses of $100 \mu \mathrm{g}, 400 \mu \mathrm{g}$, and $800 \mu \mathrm{g}$, and found that it would take 2.6 times

TABLE 2 Studies performed with hydrofluoroalkane (HFA)-formoterol pressurised metered-dose inhaler (pMDI) extra-fine aerosol

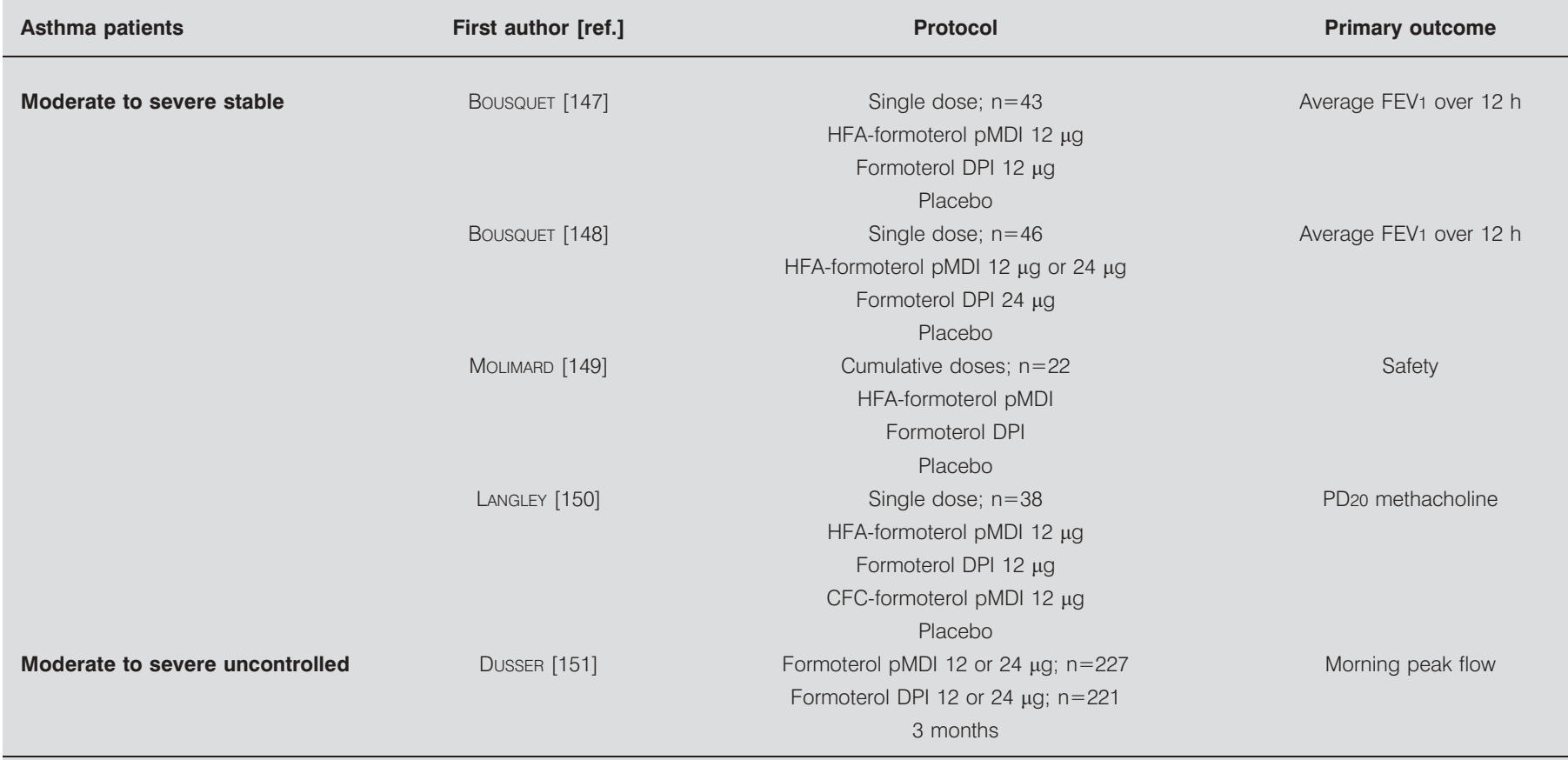

DPI: dry powder inhaler; FEV1: forced expiratory volume in $1 \mathrm{~s}$; PD20: provocative dose causing a $20 \%$ fall in FEV1. 
the dose of CFC-BDP to produce the same improvement in FEV1 obtained with HFA-BDP. The similar effectiveness of HFA-BDP at half the daily dose of CFC-BDP has been confirmed in other clinical studies in asthmatics (see later).

In the following section, we review clinical studies performed with aerosols of extra-fine particles of HFA-formoterol solution, HFA-corticosteroid solutions or the fixed combination HFA-BDP/HFA-formoterol.

Five placebo-controlled studies have been performed with HFA-formoterol solution, the only available long-acting $\beta_{2}-$ agonist (LABA) with extra-fine particles (table 2) [100, 147-151]. Most studies were short-term studies: one study evaluated safety of cumulative doses up to $96 \mu \mathrm{g}$ of HFA-formoterol [149] and another evaluated bronchoprotective effects of HFA-formoterol by assessing bronchial hyperreactivity after methacholine challenge [150]. Two studies evaluated bronchodilation after a single dose of inhaled HFA-formoterol (12 or $24 \mu \mathrm{g}$ ) by measuring the average 12-h FEV1 [147, 148]. These studies have shown a not inferior bronchodilator effect and a good tolerance compared with inhaled LABA with non-extra-fine particles. None of these studies evaluated potential improvement in asthma control, symptoms, exacerbations or health-related quality of life.

Most studies performed using extra-fine particles of HFA-BDP have been performed in patients with mild to moderate asthma insufficiently controlled by usual ICS preparations: CFC-BDP or fluticasone propionate [146, 152-155]. Two further studies were performed in subjects with stable moderate to severe asthma previously treated with CFC-BDP preparations [156, 157]. Additionally, two studies have evaluated asthmatic subjects who were not controlled by combination of LABA and ICS in the usual formulation $[75,158]$. In all these studies, comparisons were performed between ICS in usual prepara-

\begin{tabular}{|c|c|c|c|c|}
\hline Asthma patients & First author [ref.] & Protocol & $\begin{array}{l}\text { Primary } \\
\text { outcome }\end{array}$ & $\begin{array}{l}\text { Secondary } \\
\text { outcomes }\end{array}$ \\
\hline \multirow[t]{4}{*}{$\begin{array}{l}\text { Moderate to severe uncontrolled } \\
\text { with ICS }\end{array}$} & AUBIER [152] & $\begin{array}{c}\text { HFA-BDP } 800 \mu \mathrm{g} \text { per day; } \mathrm{n}=101 \\
\text { CFC-FP } 1000 \mu \mathrm{g} \text { per day; } \mathrm{n}=97 \\
8 \text { weeks }\end{array}$ & Peak flow & Symptoms \\
\hline & BusSE $[146]$ & $\begin{array}{c}\text { HFA-BDP } 100-800 \mu \mathrm{g} \text { per day; } \mathrm{n}=50 \text { to } 56 \\
\text { CFC-BDP } 100-800 \mu \mathrm{g} \text { per day; } \mathrm{n}=52 \text { to } 59 \\
6 \text { weeks }\end{array}$ & FEV 1 & $\begin{array}{l}\text { FEV } 1 \\
\text { FVC } \\
\text { FEF25-75\% } \\
\text { Symptoms }\end{array}$ \\
\hline & FAIRFAX [153] & $\begin{array}{c}\text { HFA-BDP } 400 \mu \mathrm{g} \text { per day; } \mathrm{n}=88 \\
\text { CFC-FP } 400 \mu \mathrm{g} \text { per day; } \mathrm{n}=84 \\
6 \text { weeks }\end{array}$ & Peak flow & $\begin{array}{c}\text { Symptoms } \\
\text { HRQoL }\end{array}$ \\
\hline & FOWLER [154] & $\begin{array}{l}\text { HFA-BDP } 400 \mu \mathrm{g} \text { per day; } \mathrm{n}=19 \\
\text { FP/salmeterol DPI } 200 / 100 \mu \mathrm{g} \text { per day; } \mathrm{n}=20 \\
3 \text { months }\end{array}$ & $\begin{array}{c}\text { PD20 } \\
\text { methacholine }\end{array}$ & $\begin{array}{l}\text { Symptoms } \\
\text { HRQoL }\end{array}$ \\
\hline \multirow[t]{2}{*}{ Moderate to severe stable with ICS } & FIREMAN [156] & $\begin{array}{c}\text { HFA-BDP; } \mathrm{n}=354 \\
\text { CFC-FP; } \mathrm{n}=119 \\
12 \text { months }\end{array}$ & Peak flow & Symptoms \\
\hline & JUNIPER [157] & $\begin{array}{l}\text { Open-label } \\
\text { HFA-BDP; } n=354 \\
\text { CFC-BDP; } n=119 \\
12 \text { months }\end{array}$ & HRQoL & Symptoms \\
\hline $\begin{array}{l}\text { Moderate to severe uncontrolled } \\
\text { with ICS+LABA }\end{array}$ & MOLIMARD [158] & $\begin{array}{l}\text { Open-label } \\
\text { HFA-BDP } 800 \mu \mathrm{g} \text { per day; } \mathrm{n}=149 \\
\text { FP DPI } 1000 \mu \mathrm{g} \text { per day; } \mathrm{n}=162 \\
\text { BUD DPI } 1600 \mu \mathrm{g} \text { per day; } \mathrm{n}=149\end{array}$ & $\begin{array}{l}\text { Control of } \\
\text { asthma }\end{array}$ & Symptoms \\
\hline
\end{tabular}

ICS: inhaled corticosteroid; LABA: Iong-acting $\beta$-agonist; FP: fluticasone propionate; FEV1: forced expiratory volume in $1 \mathrm{~s}$; FVC: forced vital capacity; FEF25-75\%: mean forced expiratory flow between $25 \%$ and $75 \%$ of FVC; HRQoL: health-related quality of life; DPI: dry powder inhaler; PD20: provocative dose causing a $20 \%$ fall in FEV1; BUD: budesonide. 


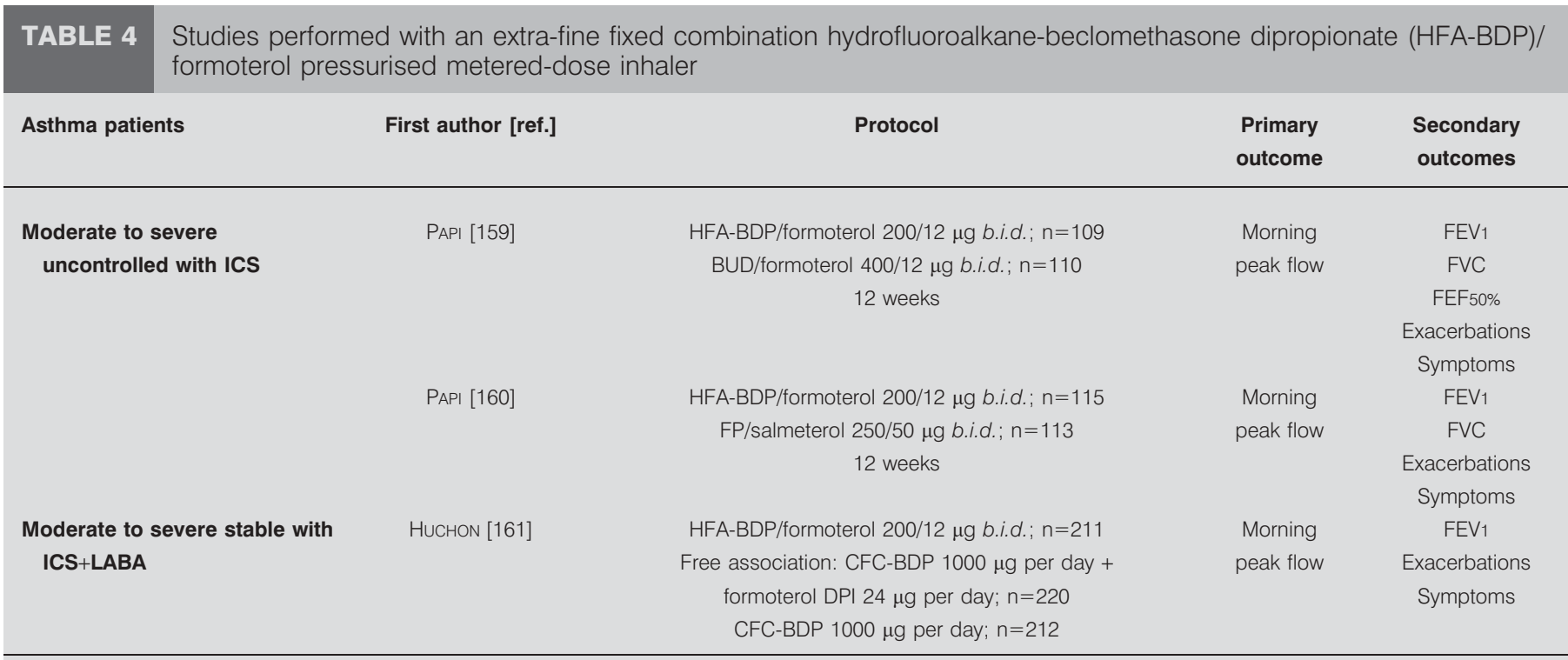

ICS: inhaled corticosteroids; LABA: long-acting $\beta$-agonist; BUD: budesonide; FEV1: forced expiratory volume in $1 \mathrm{~s}$; FVC: forced vital capacity; FEF50\%: forced expiratory flow at $50 \%$ of FVC; FP: fluticasone propionate; DPI: dry powder inhaler.

tions and extra-fine HFA-BDP at equivalent doses (table 3). With the exception of two 12-month studies [155, 156], all these studies were short-term (6-12 weeks) noninferiority studies. Asthma control has been evaluated as primary outcome in a single open-label study [158]. HFA-BDP extra-fine aerosol was found not to be inferior to budesonide and fluticasone dry powder inhaler (DPI) at equivalent doses. For patients treated with LABA, a significantly greater improvement of the asthma control questionnaire score was obtained with HFA-BDP extrafine aerosol versus fluticasone [158]. Asthma symptoms have been evaluated as secondary outcomes in eight studies. In six of these, improvement in asthma symptoms was comparable between HFA-BDP extra-fine aerosol and its comparators [151-153, 155-157]. In an open-label study, HFA-BDP extrafine aerosol significantly reduced sputum production and use of short-acting bronchodilators compared to equivalent doses of fluticasone propionate [75]. In a step-down study comparing HFA-BDP extra-fine aerosol to the salmeterol/fluticasone combination after high-dose of ICS, the combination inhaler conferred further improvements in symptoms compared with those seen with HFA-BDP extra-fine aerosol [154]. Four studies evaluated health-related quality of life as primary $[155,157]$ or secondary [153, 154] outcomes in patients treated with HFABDP extra-fine aerosol versus its comparators. Study duration was short (6-12 weeks) in all studies, except in the 12-month study by JUNIPER et al. [157]. Health-related quality of life was improved in the long-term study [157] and was equivalent in two other studies $[153,155]$. However, in the step-down study after high doses of ICS, health-related quality of life was significantly decreased in subjects treated with HFA-BDP extra-fine aerosol compared with fixed combination fluticasone/salmeterol [154].

A novel fixed combination of extra-fine particles of HFA-BDP $(100 \mu \mathrm{g}) /$ HFA-formoterol $(6 \mu \mathrm{g})$ administered via an MDI is available. Two studies have compared the extra-fine fixed combination HFA-BDP/formoterol to the existing fixed com- binations budesonide/formoterol DPI [159] and fluticasone/ salmeterol MDI [160]. These studies demonstrated their clinical noninferiority on morning peak expiratory flow (primary outcome), and on clinically relevant secondary outcomes, including FEV1, symptoms and asthma control. A third study included subjects with moderate to severe asthma who were not controlled with ICS (650-1,000 $\mu$ g per day) or with ICS/ LABA combination [161]. In the latter study, a 24-week doubleblind double-dummy randomised clinical trial, 645 patients with moderate to severe asthma uncontrolled by regular treatment with inhaled corticosteroids received regular treatment with extra-fine fixed combination HFA-BDP $(200 \mu \mathrm{g}) /$ formoterol $(12 \mu \mathrm{g})$ b.i.d., or $\mathrm{BDP}(500 \mu \mathrm{g}$ b.i.d. $)$ via $\mathrm{CFC}$ pressurised MDI and formoterol $(12 \mu \mathrm{g}$ b.i.d.) via DPI, or BDP (500 $\mu$ g b.i.d.) via CFC pressurised MDI (table 4) [161]. The extra-fine fixed combination HFA-BDP/formoterol was as effective as the free association of CFC-BDP and formoterol DPI, and superior to CFC-BDP alone in improving lung function. For the first time with a single inhaler, BDP/ formoterol was significantly superior to separate components for asthma control. Furthermore, patients treated with extrafine fixed combination $\mathrm{BDP} /$ formoterol had significant improvement on secondary outcomes, including percentage of days with asthma symptoms and numbers of exacerbations compared to the other groups of patients [161].

\section{CONCLUSION}

Both proximal and distal airways are implicated in asthma pathophysiology. Although inflammatory cell infiltrate and activation appear similar in proximal and distal airways in most cases of asthma, both the magnitude of inflammation and activation of inflammatory cells appear to be more important in distal airways in severe and uncontrolled asthma. Involvement of distal airways appears to occur early in life. Several direct and indirect methods exist to explore distal airways in asthma. Yet, easily available tests for assessing 
distal airways are not fully validated. Granulometric properties of extra-fine $(1-\mu \mathrm{m})$ particles allow them to deposit in both proximal and distal airways, whereas larger $(5-\mu \mathrm{m})$ particles deposit mostly in proximal airways. Extra-fine aerosols of LABA, ICS or ICS/LABA combination have been shown in short-term studies to be not inferior to comparators for bronchodilation and FEV1. Future studies should focus on the long-term clinical efficacy of these extra-fine inhaled medications on symptoms, control and exacerbations of asthma. These studies are required to examine the concept that targeting both proximal and distal airways improve control and natural history of asthma.

\section{STATEMENT OF INTEREST}

P-R. Burgel has received fees for speaking or consulting from Boehringer Ingelheim France, Chiesi and GSK, and his travel to the ERS/ATS meeting was funded by Boehringer Ingelheim France, Altana and GSK. P. Chanez has consulting and/or speaker arrangements with Novartis, AstraZeneca, Boehringer Ingelheim, Teva, Actélion, Chiesi and GSK; he sits on an advisory board for Centocor, and receives grant money and research support from Shering Plough. C. Delacourt has received fees for speaking from MSD, GSK, Chiesi pharmaceutical industries; and funding for travel to the ERS and ATS congresses was provided by MSD and GSK. P. Devillier has received fees from Chiesi for consultancy and speaking, and reimbursement for attending a symposium in France. J-C. Dubus acts as consultant for Meda and Novartis; travel for the MEDEC congress and participation to a symposium on "small airways in asthma" has been reimbursed by Chiesi. I. Frachon has received an educational grant from Chiesi, and has also been employed by and acted as a consultant for organisations that have an interest in the subject of the study. M. Humbert has relationships with drug companies including AB Science, Actelion, Altair, Amgen, AstraZeneca, Chiesi, GlaxoSmithKline, MSD, Novartis and Pfizer. In addition to being investigators in trials involving these companies, relationships include consultancy services and membership of scientific advisory boards. F. Laurent has received reimbursment for a symposium and fees for speaking from Chiesi. R. Louis has received research grants from GSK, AstraZeneca and Novartis, and speaker's fees from AstraZeneca, Novartis, UCB and GSK. $\mathrm{R}$. Louis has received reimbursment for attending a symposium from GSK, AstraZeneca, Novartis and UCB. A. Magnan has received a fee from Chiesi for participation at a symposium. B. Mahut has received a fee for speaking by Chiesi SA, at the "Update on the role of distal airways in asthma" workshop. T. Perez received a fee from Chiesi pharmaceuticals for speaking at the 2009 CPLF congress. In the past 5 years, N. Roche has received fees for speaking, organising education or consulting from Altana Pharma, AstraZeneca, Boehringer Ingelheim, Chiesi, GlaxoSmithKline and Pfizer. I. Tillie-Leblond has received fees for consulting from Glaxo Wellcome, AstraZeneca, Novartis and Chiesi. D. Dusser has received grants from several pharmaceutical companies for speaking (GSK, AstraZeneca, Chiesi, Boehringer Ingelheim and Novartis), received fees for consulting from Chiesi, Boehringer Ingelheim and Novartis, and has been invited by several pharmaceutical companies to attend meetings.

\section{ACKNOWLEDGEMENTS}

Affiliations are as follows. P-R. Burgel and D. Dusser: Hôpital Cochin, AP-HP, Université Paris Descartes, Paris, France; J. de Blic and B. Mahut: Hôpital Necker - Enfants Malades, AP-HP, Université Paris Descartes, Paris, France; P. Chanez: Hôpital Ste-Marguerite, AP-HM, INSERM UMR 6020, Université de la Méditerranée, Marseille, France; C. Delacourt: CHI Créteil, Créteil, France; P. Devillier: Hôpital Foch, UPRES EA 220, Université Versailles Saint-Quentin, Suresnes, France; A. Didier: Hôpital Larrey, Université de Toulouse, Toulouse, France; J-C. Dubus: Hôpital La Timone, Marseille, France; I. Frachon: CHU Cavale Blanche, Brest, France; G. Garcia and M. Humbert: Hôpital Antoine Beclère, AP-HP, Clamart, France; F. Laurent and M. Tunon de Lara: CHU de Bordeaux, Université Victor Segalen Bordeaux 2, Inserm U 855, Bordeaux, France; R. Louis: CHU de Liège - CHU N.D. des Bruyères, Chênée, Belgium; A. Magnan: CHRU de Nantes, Hôpital G \& Laënnec, Inserm U 533, Nantes, France; T. Perez and I. Tillie-Leblond: CHRU de Lille, Hôpital Albert Calmette, Lille, France; N. Roche: Hôpital de l'Hôtel-Dieu, AP-HP, Université Paris Descartes, Paris, France.

\section{REFERENCES}

1 Yanai M, Sekizawa K, Ohrui T, et al. Site of airway obstruction in pulmonary disease: direct measurement of intrabronchial pressure. J Appl Physiol 1992; 72: 1016-1023.

2 National Heart Lung and Blood Institute and National Institutes of Health. Global Strategy for Asthma Management and Prevention. WHO/NHLBI workshop report 2006. Bethesda, National Institutes of Health, 2006.

3 Bateman ED, Boushey HA, Bousquet J, et al. Can guideline-defined asthma control be achieved? The Gaining Optimal Asthma Control study. Am J Respir Crit Care Med 2004; 170: 836-844.

4 Morgan WJ, Stern DA, Sherrill DL, et al. Outcome of asthma and wheezing in the first 6 years of life: follow-up through adolescence. Am J Respir Crit Care Med 2005; 172: 1253-1258.

5 Van Ganse E, Antonicelli L, Zhang Q, et al. Asthmarelated resource use and cost by GINA classification of severity in three European countries. Respir Med 2006; 100: 140-147.

6 Van Ganse E, Laforest L, Pietri G, et al. Persistent asthma: disease control, resource utilisation and direct costs. Eur Respir J 2002; 20: 260-267.

7 Tillie-Leblond I, Magnan A, Pauli G, et al. Asthma and allergy: short texts and recommendations of the expert conference of the French Speaking Pneumology Society (SPLF), in partnership with the French Society of Allergology and Clinical Immunology (SFAIC), the French Society of Occupational Medicine (SFMT) and the "Asthma-Allergy" association. Respir Med 2008; 102: 1483-1493.

8 Burri PH. Fetal and postnatal development of the lung. Annu Rev Physiol 1984; 46: 617-628.

9 Sparrow MP, Weichselbaum M, McCray PB. Development of the innervation and airway smooth muscle in human fetal lung. Am J Respir Cell Mol Biol 1999; 20: 550-560. 
10 Rosenthal M, Bush A. The growing lung. Normal development, and the long-term effects of pre- and post-natal insults. In: Bush A, Carlsen K-H, Zach MS, eds. Growing Up with Lung Disease: the Lung in Transition to Adult Life. Eur Respir Mon 2002; 19: 1-24.

11 Bjornson CL, Mitchell I. Gender differences in asthma in childhood and adolescence. J Gend Specif Med. 2000; 3: 57-61.

12 Boezen HM, Jansen DF, Postma DS. Sex and gender differences in lung development and their clinical significance. Clin Chest Med 2004; 25: 237-245.

13 Trian T, Benard G, Begueret H, et al. Bronchial smooth muscle remodeling involves calcium-dependent enhanced mitochondrial biogenesis in asthma. J Exp Med 2007; 204: 3173-3181.

14 Jeffery PK. The development of large and small airways. Am J Respir Crit Care Med 1998; 157: S174-S180.

15 Bousquet J, Jeffery PK, Busse WW, et al. Asthma. From bronchoconstriction to airways inflammation and remodeling. Am J Respir Crit Care Med 2000; 161: 1720-1745.

16 Zhang JY, Wenzel SE. Tissue and BAL based biomarkers in asthma. Immunol Allergy Clin North Am 2007; 27: 623632; vi.

17 Bergeron C, Tulic MK, Hamid Q. Tools used to measure airway remodelling in research. Eur Respir J 2007; 29: 596-604.

18 Tulic MK, Christodoulopoulos P, Hamid Q. Small airway inflammation in asthma. Respir Res 2001; 2: 333-339.

19 Faul JL, Tormey VJ, Leonard C, et al. Lung immunopathology in cases of sudden asthma death. Eur Respir J 1997; 10: 301-307.

20 Synek M, Beasley R, Frew AJ, et al. Cellular infiltration of the airways in asthma of varying severity. Am J Respir Crit Care Med 1996; 154: 224-230.

21 Carroll NG, Mutavdzic S, James AL. Increased mast cells and neutrophils in submucosal mucous glands and mucus plugging in patients with asthma. Thorax. 2002; 57: 677-682.

22 Carroll NG, Mutavdzic S, James AL. Distribution and degranulation of airway mast cells in normal and asthmatic subjects. Eur Respir J 2002; 19: 879-885.

23 Haley KJ, Sunday ME, Wiggs BR, et al. Inflammatory cell distribution within and along asthmatic airways. Am J Respir Crit Care Med 1998; 158: 565-572.

24 Kuyper LM, Pare PD, Hogg JC, et al. Characterization of airway plugging in fatal asthma. Am J Med 2003; 115: 6-11.

25 Kuwano K, Bosken CH, Pare PD, et al. Small airways dimensions in asthma and in chronic obstructive pulmonary disease. Am Rev Respir Dis 1993; 148: 1220-1225.

26 Hamid Q, Song Y, Kotsimbos TC, et al. Inflammation of small airways in asthma. J Allergy Clin Immunol 1997; 100: 44-51.

27 Minshall EM, Hogg JC, Hamid QA. Cytokine mRNA expression in asthma is not restricted to the large airways. J Allergy Clin Immunol 1998; 101: 386-390.

28 Taha RA, Minshall EM, Miotto D, et al. Eotaxin and monocyte chemotactic protein-4 mRNA expression in small airways of asthmatic and nonasthmatic individuals. J Allergy Clin Immunol 1999; 103: 476-483.

29 Balzar S, Chu HW, Strand M, et al. Relationship of small airway chymasepositive mast cells and lung function in severe asthma. Am J Respir Crit Care Med 2005; 171 431-439.

30 Balzar S, Wenzel SE, Chu HW. Transbronchial biopsy as a tool to evaluate small airways in asthma. Eur Respir J 2002; 20: 254-259.

31 Wenzel SE, Szefler SJ, Leung DY, et al. Bronchoscopic evaluation of severe asthma. Persistent inflammation associated with high dose glucocorticoids. Am J Respir Crit Care Med 1997; 156: 737-743.

32 Kraft M, Martin RJ, Wilson S, et al. Lymphocyte and eosinophil influx into alveolar tissue in nocturnal asthma. Am J Respir Crit Care Med 1999; 159: 228-234.

33 Martin RJ, Cicutto LC, Smith HR, et al. Airways inflammation in nocturnal asthma. Am Rev Respir Dis 1991; 143: 351-357.

34 Jarjour NN, Busse WW, Calhoun WJ. Enhanced production of oxygen radicals in nocturnal asthma. Am Rev Respir Dis 1992; 146: 905-911.

35 Rojas-Ramos E, Avalos AF, Perez-Fernandez L, et al. Role of the chemokines RANTES, monocyte chemotactic proteins-3 and -4 , and eotaxins- 1 and -2 in childhood asthma. Eur Respir J 2003; 22: 310-316.

36 Just J, Fournier L, Momas I, et al. Clinical significance of bronchoalveolar eosinophils in childhood asthma. J Allergy Clin Immunol 2002; 110: 42-44.

37 Marguet C, Jouen-Boedes F, Dean TP, et al. Bronchoalveolar cell profiles in children with asthma, infantile wheeze, chronic cough, or cystic fibrosis. Am J Respir Crit Care Med 1999; 159: 1533-1540.

38 Stevenson EC, Turner G, Heaney LG, et al. Bronchoalveolar lavage findings suggest two different forms of childhood asthma. Clin Exp Allergy 1997; 27: 1027-1035.

39 Brown V, Warke TJ, Shields MD, et al. T cell cytokine profiles in childhood asthma. Thorax 2003; 58: 311-316.

40 Marguet C, Dean TP, Warner JO. Soluble intercellular adhesion molecule-1 (sICAM1) and interferon- $\gamma$ in bronchoalveolar lavage fluid from children with airway diseases. Am J Respir Crit Care Med 2000; 162: 1016-1022.

41 Azevedo I, de Blic J, Dumarey $\mathrm{CH}$, et al. Increased spontaneous release of tumour necrosis factor- $\alpha$ by alveolar macrophages from wheezy infants. Eur Respir J 1997; 10: 1767-1773.

42 Azevedo I, de Blic J, Scheinmann P, et al. Enhanced arachidonic acid metabolism in alveolar macrophages from wheezy infants. Modulation by dexamethasone. Am J Respir Crit Care Med 1995; 152: 1208-1214.

43 Tang LF, Du LZ, Chen ZM, et al. Levels of matrix metalloproteinase- 9 and its inhibitor in bronchoalveolar lavage cells of asthmatic children. Fetal Pediatr Pathol 2006; 25: 1-7.

44 Doherty GM, Kamath SV, de Courcey F, et al. Children with stable asthma have reduced airway matrix metalloproteinase-9 and matrix metalloproteinase-9/tissue inhibitor of metalloproteinase-1 ratio. Clin Exp Allergy 2005; 35: 1168-1174.

45 Carroll N, Cooke C, James A. The distribution of eosinophils and lymphocytes in the large and small airways of asthmatics. Eur Respir J 1997; 10: 292-300.

46 Belda J, Leigh R, Parameswaran K, et al. Induced sputum cell counts in healthy adults. Am J Respir Crit Care Med 2000; 161: 475-478. 
47 Spanevello A, Confalonieri M, Sulotto F, et al. Induced sputum cellularity. Reference values and distribution in normal volunteers. Am J Respir Crit Care Med 2000; 162: 1172-1174.

48 Balbi B, Pignatti P, Corradi M, et al. Bronchoalveolar lavage, sputum and exhaled clinically relevant inflammatory markers: values in healthy adults. Eur Respir J 2007; 30: 769-781.

49 Fahy JV, Wong H, Liu J, et al. Comparison of samples collected by sputum induction and bronchoscopy from asthmatic and healthy subjects. Am J Respir Crit Care Med 1995; 152: 53-58.

50 Keatings VM, Evans DJ, O'Connor BJ, et al. Cellular profiles in asthmatic airways: a comparison of induced sputum, bronchial washings, and bronchoalveolar lavage fluid. Thorax 1997; 52: 372-374.

51 Maestrelli P, Saetta M, Di Stefano A, et al. Comparison of leukocyte counts in sputum, bronchial biopsies, and bronchoalveolar lavage. Am J Respir Crit Care Med 1995; 152: 1926-1931.

52 Pizzichini E, Pizzichini MM, Kidney JC, et al. Induced sputum, bronchoalveolar lavage and blood from mild asthmatics: inflammatory cells, lymphocyte subsets and soluble markers compared. Eur Respir J 1998; 11: 828-834.

53 Mostgaard G, Siersted HC, Hansen HS, et al. Reduced forced expiratory flow in schoolchildren with respiratory symptoms: the Odense Schoolchild Study. Respir Med 1997; 91: 443-448.

54 Nakadate T, Kagawa J. Pulmonary function development in children with past history of asthma. J Epidemiol Community Health 1992; 46: 437-442.

55 Berhane K, McConnell R, Gilliland F, et al. Sex-specific effects of asthma on pulmonary function in children. Am J Respir Crit Care Med 2000; 162: 1723-1730.

56 Illi S, von Mutius E, Lau S, et al. Perennial allergen sensitisation early in life and chronic asthma in children: a birth cohort study. Lancet 2006; 368: 763-770.

57 Gilliland FD, Berhane K, Li YF, et al. Effects of early onset asthma and in utero exposure to maternal smoking on childhood lung function. Am J Respir Crit Care Med 2003; 167: 917-924.

58 Anand D, Stevenson CJ, West CR, et al. Lung function and respiratory health in adolescents of very low birth weight. Arch Dis Child 2003; 88: 135-138.

59 Stern DA, Morgan WJ, Wright AL, et al. Poor airway function in early infancy and lung function by age 22 years: a non-selective longitudinal cohort study. Lancet 2007; 370: 758-764.

60 Rappaport EB, Gilliland FD, Linn WS, et al. Impact of respiratory illness on expiratory flow rates in normal, asthmatic, and allergic children. Pediatr Pulmonol 2002; 34: 112-121.

61 Strope GL, Stewart PW, Henderson FW, et al. Lung function in school-age children who had mild lower respiratory illnesses in early childhood. Am Rev Respir Dis 1991; 144: 655-662.

62 Delacourt C, Benoist MR, Waernessyckle S, et al. Relationship between bronchial responsiveness and clinical evolution in infants who wheeze: a four-year prospective study. Am J Respir Crit Care Med 2001; 164: 1382-1386.
63 Lowe LA, Simpson A, Woodcock A, et al. Wheeze phenotypes and lung function in preschool children. Am J Respir Crit Care Med 2005; 171: 231-237.

64 Delacourt C, Benoist MR, Le Bourgeois M, et al. Relationship between bronchial hyperresponsiveness and impaired lung function after infantile asthma. PLoS One 2007; 2: e1180.

65 Rasmussen F, Taylor DR, Flannery EM, et al. Risk factors for airway remodeling in asthma manifested by a low postbronchodilator FEV1/vital capacity ratio: a longitudinal population study from childhood to adulthood. Am J Respir Crit Care Med 2002; 165: 1480-1488.

66 Sears MR, Greene JM, Willan AR, et al. A longitudinal, population-based, cohort study of childhood asthma followed to adulthood. N Engl J Med 2003; 349: 1414-1422.

67 Hogg JC, Macklem PT, Thurlbeck WM. Site and nature of airway obstruction in chronic obstructive lung disease. N Engl J Med 1968; 278: 1355-1360.

68 Wiggs BR, Bosken C, Pare PD, et al. A model of airway narrowing in asthma and in chronic obstructive pulmonary disease. Am Rev Respir Dis 1992; 145: 1251-1258.

69 Wagner EM, Bleecker ER, Permutt S, et al. Direct assessment of small airways reactivity in human subjects. Am J Respir Crit Care Med 1998; 157: 447-452.

70 Gelb AF, Zamel N. Lung elastic recoil in acute and chronic asthma. Curr Opin Pulm Med 2002; 8: 50-53.

71 Lapp NL, Hyatt RE. Some factors affecting the relationship of maximal expiratory flow to lung volume in health and disease. Dis Chest 1967; 51: 475-481.

72 Bahceciler NN, Barlan IB, Nuhoglu Y, et al. Risk factors for the persistence of respiratory symptoms in childhood asthma. Ann Allergy Asthma Immunol 2001; 86: 449-455.

73 Droste JH, Wieringa $\mathrm{MH}$, Weyler JJ, et al. Lung function measures and their relationship to respiratory symptoms in 7- and 8-year-old children. Pediatr Pulmonol 1999; 27: 260-266.

74 Marseglia GL, Cirillo I, Vizzaccaro A, et al. Role of forced expiratory flow at $25-75 \%$ as an early marker of small airways impairment in subjects with allergic rhinitis. Allergy Asthma Proc 2007; 28: 74-78.

75 Thongngarm $\mathrm{T}$, Silkoff PE, Kossack WS, et al. Hydrofluoroalkane-134A beclomethasone or chlorofluorocarbon fluticasone: effect on small airways in poorly controlled asthma. J Asthma 2005; 42: 257-263.

76 Hansen JE, Sun XG, Wasserman K. Discriminating measures and normal values for expiratory obstruction. Chest 2006; 129: 369-377.

77 Pellegrino R, Viegi G, Brusasco V, et al. Interpretative strategies for lung function tests. Eur Respir J 2005; 26: 948-968.

78 Gibson GJ. Pulmonary hyperinflation a clinical overview. Eur Respir J 1996; 9: 2640-2649.

79 Dykstra BJ, Scanlon PD, Kester MM, et al. Lung volumes in 4,774 patients with obstructive lung disease. Chest 1999; 115: 68-74.

80 Pellegrino R, Brusasco V. On the causes of lung hyperinflation during bronchoconstriction. Eur Respir J 1997; 10: 468-475.

81 Gelb AF, Zamel N, Hogg JC, et al. Pseudophysiologic emphysema resulting from severe small-airways disease. Am J Respir Crit Care Med 1998; 158: 815-819. 
82 Sutherland ER, Martin RJ, Bowler RP, et al. Physiologic correlates of distal lung inflammation in asthma. J Allergy Clin Immunol 2004; 113: 1046-1050.

83 Sorkness RL, Bleecker ER, Busse WW, et al. Lung function in adults with stable but severe asthma: air trapping and incomplete reversal of obstruction with bronchodilation. J Appl Physiol 2008; 104: 394-403.

84 Wenzel SE, Schwartz LB, Langmack EL, et al. Evidence that severe asthma can be divided pathologically into two inflammatory subtypes with distinct physiologic and clinical characteristics. Am J Respir Crit Care Med 1999; 160: 1001-1008.

85 Stanescu D. Was it just our problem, or yours too? Errors in body plethysmography, in infants, children, and adults. Pediatr Pulmonol 1991; 11: 285-288.

86 Phagoo SB, Wilson NM, Silverman M. Evaluation of the interrupter technique for measuring change in airway resistance in 5-yr-old asthmatic children. Pediatr Pulmonaol 1995; 20: 387-395.

87 Grimby G, Takishima T, Graham W, et al. Frequency dependence of flow resistance in patients with obstructive lung disease. J Clin Invest 1968; 47: 1455-1465.

88 Cavalcanti JV, Lopes AJ, Jansen JM, et al. Detection of changes in respiratory mechanics due to increasing degrees of airway obstruction in asthma by the forced oscillation technique. Respir Med 2006; 100: 2207-2219.

89 Goldman MD, Saadeh C, Ross D. Clinical applications of forced oscillation to assess peripheral airway function. Respir Physiol Neurobiol 2005; 148: 179-194.

90 Kaminsky DA, Irvin CG, Lundblad L, et al. Oscillation mechanics of the human lung periphery in asthma. J Appl Physiol 2004; 97: 1849-1858.

91 Tgavalekos NT, Musch G, Harris RS, et al. Relationship between airway narrowing, patchy ventilation and lung mechanics in asthmatics. Eur Respir J 2007; 29: 1174-1181.

92 Delacourt C, Lorino H, Herve-Guillot M, et al. Use of the forced oscillation technique to assess airway obstruction and reversibility in children. Am J Respir Crit Care Med 2000; 161: 730-736.

93 Bourdin A, Paganin F, Prefaut C, et al. Nitrogen washout slope in poorly controlled asthma. Allergy 2006; 61: 85-89.

94 in 't Veen JC, Beekman AJ, Bel EH, et al. Recurrent exacerbations in severe asthma are associated with enhanced airway closure during stable episodes. Am J Respir Crit Care Med 2000; 161: 1902-1906.

95 Verbanck S, Schuermans D, Van Muylem A, et al. Ventilation distribution during histamine provocation. J Appl Physiol 1997; 83: 1907-1916.

96 Verbanck S, Schuermans D, Paiva M, et al. Nonreversible conductive airway ventilation heterogeneity in mild asthma. J Appl Physiol 2003; 94: 1380-1386.

97 Verbanck S, Schuermans D, Paiva M, et al. The functional benefit of antiinflammatory aerosols in the lung periphery. J Allergy Clin Immunol 2006; 118: 340-346.

98 Michils A, Baldassarre S, Van Muylem A. Exhaled nitric oxide and asthma control: a longitudinal study in unselected patients. Eur Respir J 2008; 31: 539-546.

99 Smith AD, Cowan JO, Brassett KP, et al. Use of exhaled nitric oxide measurements to guide treatment in chronic asthma. N Engl J Med 2005; 352: 2163-2173.
100 Zacharasiewicz A, Wilson N, Lex C, et al. Clinical use of noninvasive measurements of airway inflammation in steroid reduction in children. Am J Respir Crit Care Med 2005; 171: 1077-1082.

101 Dweik RA, Laskowski D, Abu-Soud HM, et al. Nitric oxide synthesis in the lung. Regulation by oxygen through a kinetic mechanism. J Clin Invest 1998; 101: 660-666.

102 Lane C, Knight D, Burgess S, et al. Epithelial inducible nitric oxide synthase activity is the major determinant of nitric oxide concentration in exhaled breath. Thorax 2004; 59: 757-760.

103 Lehtimaki L, Kankaanranta H, Saarelainen S, et al. Extended exhaled NO measurement differentiates between alveolar and bronchial inflammation. Am J Respir Crit Care Med 2001; 163: 1557-1561.

104 Paredi P, Kharitonov SA, Loukides S, et al. Exhaled nitric oxide is increased in active fibrosing alveolitis. Chest 1999; 115: 1352-1356.

105 Delclaux C, Mahut B, Zerah-Lancner F, et al. Increased nitric oxide output from alveolar origin during liver cirrhosis versus bronchial source during asthma. Am J Respir Crit Care Med 2002; 165: 332-337.

106 Tiev KP, Cabane J, Aubourg F, et al. Severity of scleroderma lung disease is related to alveolar concentration of nitric oxide. Eur Respir J 2007; 30: 26-30.

107 Silkoff PE, McClean PA, Slutsky AS, et al. Marked flowdependence of exhaled nitric oxide using a new technique to exclude nasal nitric oxide. Am J Respir Crit Care Med 1997; 155: 260-267.

108 George SC, Hogman M, Permutt S, et al. Modeling pulmonary nitric oxide exchange. J Appl Physiol 2004; 96: 831-839.

109 Mahut B, Louis B, Zerah-Lancner F, et al. Validity criteria and comparison of analytical methods of flow-independent exhaled NO parameters. Respir Physiol Neurobiol 2006; 153: 148-156.

110 Berry M, Hargadon B, Morgan A, et al. Alveolar nitric oxide in adults with asthma: evidence of distal lung inflammation in refractory asthma. Eur Respir J 2005; 25: 986-991.

111 Iijima H, Duguet A, Eum SY, et al. Nitric oxide and protein nitration are eosinophil dependent in allergenchallenged mice. Am J Respir Crit Care Med 2001; 163: 1233-1240.

112 Lehtimaki L, Kankaanranta H, Saarelainen S, et al. Peripheral inflammation in patients with asthmatic symptoms but normal lung function. J Asthma 2005; 42: 605-609.

113 Mahut B, Delacourt C, Zerah-Lancner F, et al. Increase in alveolar nitric oxide in the presence of symptoms in childhood asthma. Chest 2004; 125: 1012-1018.

114 Battaglia S, den Hertog H, Timmers MC, et al. Small airways function and molecular markers in exhaled air in mild asthma. Thorax 2005; 60: 639-644.

115 Lynch DA, Newell JD, Tschomper BA, et al. Uncomplicated asthma in adults: comparison of CT appearance of the lungs in asthmatic and healthy subjects. Radiology 1993; 188: 829-833.

116 Paganin F, Seneterre E, Chanez P, et al. Computed tomography of the lungs in asthma: influence of disease 
severity and etiology. Am J Respir Crit Care Med 1996; 153: 110-114.

117 Park JW, Hong YK, Kim CW, et al. High-resolution computed tomography in patients with bronchial asthma: correlation with clinical features, pulmonary functions and bronchial hyperresponsiveness. I Investig Allergol Clin Immunol 1997; 7: 186-192.

118 Stern EJ, Webb WR. Dynamic imaging of lung morphology with ultrafast high-resolution computed tomography. J Thorac Imaging 1993; 8: 273-282.

119 Kalender WA, Fichte H, Bautz W, et al. Semiautomatic evaluation procedures for quantitative CT of the lung. J Comput Assist Tomogr 1991; 15: 248-255.

120 Kalender WA, Rienmuller R, Seissler W, et al. Measurement of pulmonary parenchymal attenuation: use of spirometric gating with quantitative CT. Radiology 1990; 175: 265-268.

121 Beigelman-Aubry C, Capderou A, Grenier PA, et al. Mild intermittent asthma: CT assessment of bronchial crosssectional area and lung attenuation at controlled lung volume. Radiology 2002; 223: 181-187.

122 Tunon-de-Lara JM, Laurent F, Giraud V, et al. Air trapping in mild and moderate asthma: effect of inhaled corticosteroids. J Allergy Clin Immunol 2007; 119: 583-590.

123 Goldin JG, McNitt-Gray MF, Sorenson SM, et al. Airway hyperreactivity: assessment with helical thin-section CT. Radiology 1998; 208: 321-329.

124 Laurent F, Latrabe V, Raherison C, et al. Functional significance of air trapping detected in moderate asthma. Eur Radiol 2000; 10: 1404-1410.

125 Jensen SP, Lynch DA, Brown KK, et al. High-resolution CT features of severe asthma and bronchiolitis obliterans. Clin Radiol 2002; 57: 1078-1085.

126 Lee KW, Chung SY, Yang I, et al. Correlation of aging and smoking with air trapping at thin-section CT of the lung in asymptomatic subjects. Radiology 2000; 214: 831-836.

127 Ueda T, Niimi A, Matsumoto H, et al. Role of small airways in asthma: investigation using high-resolution computed tomography. J Allergy Clin Immunol 2006; 118: 1019-1025.

128 Lee YM, Park JS, Hwang JH, et al. High-resolution CT findings in patients with near-fatal asthma: comparison of patients with mild-to-severe asthma and normal control subjects and changes in airway abnormalities following steroid treatment. Chest 2004; 126: 1840-1848.

129 Jain N, Covar RA, Gleason MC, et al. Quantitative computed tomography detects peripheral airway disease in asthmatic children. Pediatr Pulmonol 2005; 40: 211-218.

130 Goldin JG, Tashkin DP, Kleerup EC, et al. Comparative effects of hydrofluoroalkane and chlorofluorocarbon beclomethasone dipropionate inhalation on small airways: assessment with functional helical thin-section computed tomography. J Allergy Clin Immunol 1999; 104: S258-S267.

131 Niimi A, Matsumoto $H$, Takemura $M$, et al. Clinical assessment of airway remodeling in asthma: utility of computed tomography. Clin Rev Allergy Immunol 2004; 27: 45-58.

132 Zeidler MR, Kleerup EC, Goldin JG, et al. Montelukast improves regional air-trapping due to small airways obstruction in asthma. Eur Respir J 2006; 27: 307-315.
133 Altes TA, Powers PL, Knight-Scott J, et al. Hyperpolarized ${ }^{3} \mathrm{He}$ MR lung ventilation imaging in asthmatics: preliminary findings. J Magn Reson Imaging 2001; 13: 378-384.

134 Samee S, Altes T, Powers P, et al. Imaging the lungs in asthmatic patients by using hyperpolarized helium-3 magnetic resonance: assessment of response to methacholine and exercise challenge. J Allergy Clin Immunol 2003; 111: 1205-1211.

135 Pellegrino R, Biggi A, Papaleo A, et al. Regional expiratory flow limitation studied with Technegas in asthma. J Appl Physiol 2001; 91: 2190-2198.

136 Tgavalekos NT, Tawhai M, Harris RS, et al. Identifying airways responsible for heterogeneous ventilation and mechanical dysfunction in asthma: an image functional modeling approach. J Appl Physiol 2005; 99: 2388-2397.

137 Venegas JG, Schroeder T, Harris S, et al. The distribution of ventilation during bronchoconstriction is patchy and bimodal: a PET imaging study. Respir Physiol Neurobiol 2005; 148: 57-64.

138 Kraft M, Cairns CB, Ellison MC, et al. Improvements in distal lung function correlate with asthma symptoms after treatment with oral montelukast. Chest 2006; 130: 1726-1732.

139 Stelmach I, Grzelewski T, Bobrowska-Korzeniowska M, et al. A randomized, double-blind trial of the effect of anti-asthma treatment on lung function in children with asthma. Pulm Pharmacol Ther 2007; 20: 691-700.

140 Nieto A, Pamies R, Oliver F, et al. Montelukast improves pulmonary function measured by impulse oscillometry in children with asthma (MIO study). Respir Med 2006; 100: 1180-1185.

141 Usmani OS, Biddiscombe MF, Barnes PJ. Regional lung deposition and bronchodilator response as a function of $\beta_{2}$-agonist particle size. Am J Respir Crit Care Med 2005; 172: $1497-1504$.

142 Asgharian B, Hofmann W, Bergmann R. Particle deposition in a multiple-path model of the human lung. Aerosol Sci Technol 2001; 34: 332-339.

$143 \mathrm{Kim}$ CS. Methods of calculating lung delivery and deposition of aerosol particles. Respir Care 2000; 45: 695-711.

144 Leach CL, Davidson PJ, Hasselquist BE, et al. Lung deposition of hydrofluoroalkane-134a beclomethasone is greater than that of chlorofluorocarbon fluticasone and chlorofluorocarbon beclomethasone: a cross-over study in healthy volunteers. Chest 2002; 122: 510-516.

145 Seale JP, Harrison LI. Effect of changing the fine particle mass of inhaled beclomethasone dipropionate on intrapulmonary deposition and pharmacokinetics. Respir Med 1998; 92: Suppl. A, 9-15.

146 Busse WW, Brazinsky S, Jacobson K, et al. Efficacy response of inhaled beclomethasone dipropionate in asthma is proportional to dose and is improved by formulation with a new propellant. J Allergy Clin Immunol 1999; 104: 1215-1222.

147 Bousquet J, Huchon G, Leclerc V, et al. A randomized, double-blind, double-dummy, single-dose, efficacy crossover trial comparing formoterol-HFA (pMDI) versus formoterol-DPI (Aerolizer) and placebo (pMDI or 
Aerolizer) in asthmatic patients. Respiration 2005; 72: Suppl. 1, 6-12.

148 Bousquet J, Guenole E, Duvauchelle T, et al. A randomized, double-blind, double-dummy, single-dose, crossover trial evaluating the efficacy and safety profiles of two dose levels (12 and $24 \mu \mathrm{g}$ ) of formoterol-HFA (pMDI) versus those of a dose level $(24 \mu \mathrm{g})$ of formoterol-DPI (Foradil/Aerolizer) and of placebo (pMDI or Aerolizer) in moderate to severe asthmatic patients. Respiration 2005; 72: Suppl. 1, 13-19.

149 Molimard M, Guenole E, Duvauchelle T, et al. A randomized, double-blind, double-dummy, safety crossover trial comparing cumulative doses up to $96 \mu \mathrm{g}$ of formoterol delivered via an HFA-134a-propelled pMDI versus same cumulative doses of formoterol DPI and placebo in asthmatic patients. Respiration 2005; 72: Suppl. $1,28-34$.

150 Langley SJ, Houghton CM, Singh SD. Bronchoprotective and bronchodilator effects of an HFA pMDI versus a CFC pMDI and a DPI containing formoterol in asthma patients. Respiration 2005; 72: Suppl. 1, 35-37.

151 Dusser D, Vicaut E, Lefrancois G. Double-blind, doubledummy, multinational, multicenter, parallel-group design clinical trial of clinical non-inferiority of formoterol $12 \mu \mathrm{g} /$ unit dose in a b.i.d. regimen administered via an HFA-propellant-pMDI or a dry powder inhaler in a 12-week treatment period of moderate to severe stable persistent asthma in adult patients. Respiration 2005; 72: Suppl. 1, 20-27.

152 Aubier M, Wettenger R, Gans SJ. Efficacy of HFAbeclomethasone dipropionate extra-fine aerosol (800 $\mu \mathrm{g}$. day $\left.^{-1}\right)$ versus HFA-fluticasone propionate $\left(1000 \mu \mathrm{g} \cdot\right.$ day $\left.^{-1}\right)$ in patients with asthma. Respir Med 2001; 95: 212-220.

153 Fairfax A, Hall I, Spelman R. A randomized, double-blind comparison of beclomethasone dipropionate extrafine aerosol and fluticasone propionate. Ann Allergy Asthma Immunol 2001; 86: 575-582.

154 Fowler SJ, Currie GP, Lipworth BJ. Step-down therapy with low-dose fluticasonesalmeterol combination or medium-dose hydrofluoroalkane 134a-beclomethasone alone. J Allergy Clin Immunol 2002; 109: 929-935.

155 Juniper EF, Buist AS. Health-related quality of life in moderate asthma: $400 \mu \mathrm{g}$ hydrofluoroalkane beclomethasone dipropionate versus $800 \mu \mathrm{g}$ chlorofluorocarbon beclomethasone dipropionate. The Study Group. Chest 1999; 116: 1297-1303.

156 Fireman P, Prenner BM, Vincken W, et al. Long-term safety and efficacy of a chlorofluorocarbon-free beclomethasone dipropionate extrafine aerosol. Ann Allergy Asthma Immunol 2001; 86: 557-565.

157 Juniper EF, Price DB, Stampone PA, et al. Clinically important improvements in asthma-specific quality of life, but no difference in conventional clinical indexes in patients changed from conventional beclomethasone dipropionate to approximately half the dose of extrafine beclomethasone dipropionate. Chest 2002; 121: 1824-1832.

158 Molimard M, Martinat Y, Rogeaux Y, et al. Improvement of asthma control with beclomethasone extrafine aerosol compared to fluticasone and budesonide. Respir Med 2005; 99: 770-778.

159 Papi A, Paggiaro PL, Nicolini G, et al. Beclomethasone/ formoterol versus budesonide/formoterol combination therapy in asthma. Eur Respir J 2007; 29: 682-689.

160 Papi A, Paggiaro P, Nicolini G, et al. Beclomethasone/ formoterol versus fluticasone/salmeterol inhaled combination in moderate to severe asthma. Allergy 2007; 62: 1182-1188.

161 Huchon G, Magnussen H, Chuchalin A, et al. Lung function and asthma control with beclomethasone and formoterol in a single inhaler. Respir Med 2009; 103: 41-49. 